\title{
Erratum: Parasitic diarrheal disease: drug development and targets
}

OPEN ACCESS

Approved by:

Microbiology Editorial Office,

Frontiers, Switzerland

${ }^{*}$ Correspondence:

Frontiers Production Office production.office@frontiersin.org

Specialty section:

This article was submitted to Antimicrobials, Resistance and

Chemotherapy,

a section of the journal

Frontiers in Microbiology

Received: 11 November 2015 Accepted: 11 November 2015

Published: 16 November 2015

Citation:

Frontiers Production Office (2015) Erratum: Parasitic diarrheal disease: drug development and targets.

Front. Microbiol. 6:1328 doi: 10.3389/fmicb.2015.01328

\author{
Frontiers Production Office* \\ Frontiers Production Office, Frontiers, Lausanne, Switzerland
}

Keywords: diarrhea, causative parasitic agents, chemotherapy, drug targets, therapeutic developments

\section{An erratum on}

Parasitic diarrheal disease: drug development and targets

by Azam, A., Peerzada, M. N., and Ahmad, K. (2015). Front. Microbiol. 6:1183. doi: $10.3389 /$ fmicb.2015.01183

Reason for Erratum:

Due to a technical error, the Supplementary Material for the article, containing the chemical structures was omitted from the published article. The publisher apologizes for this error and the correct Supplementary Material has been added to the original article.

This error does not change the scientific conclusions of the article in any way.

Copyright $\odot 2015$ Frontiers Production Office. This is an open-access article distributed under the terms of the Creative Commons Attribution License (CC BY). The use, distribution or reproduction in other forums is permitted, provided the original author(s) or licensor are credited and that the original publication in this journal is cited, in accordance with accepted academic practice. No use, distribution or reproduction is permitted which does not comply with these terms. 